\title{
Effect of Actinobacteria and Pseudomonas spp. against Sclerotium rolfsii in Groundnut
}

\author{
K.P. Roopa ${ }^{1 *}$ and P.U. Krishnaraj ${ }^{2}$ \\ ${ }^{1}$ Department of Biotechnology, University of Agricultural Sciences, Dharwad, Karnataka, India \\ ${ }^{2}$ Department of Agricultural Microbiology, College of Agriculture, Vijayapura, Karnataka, India \\ *Corresponding author
}

\section{A B S T R A C T}

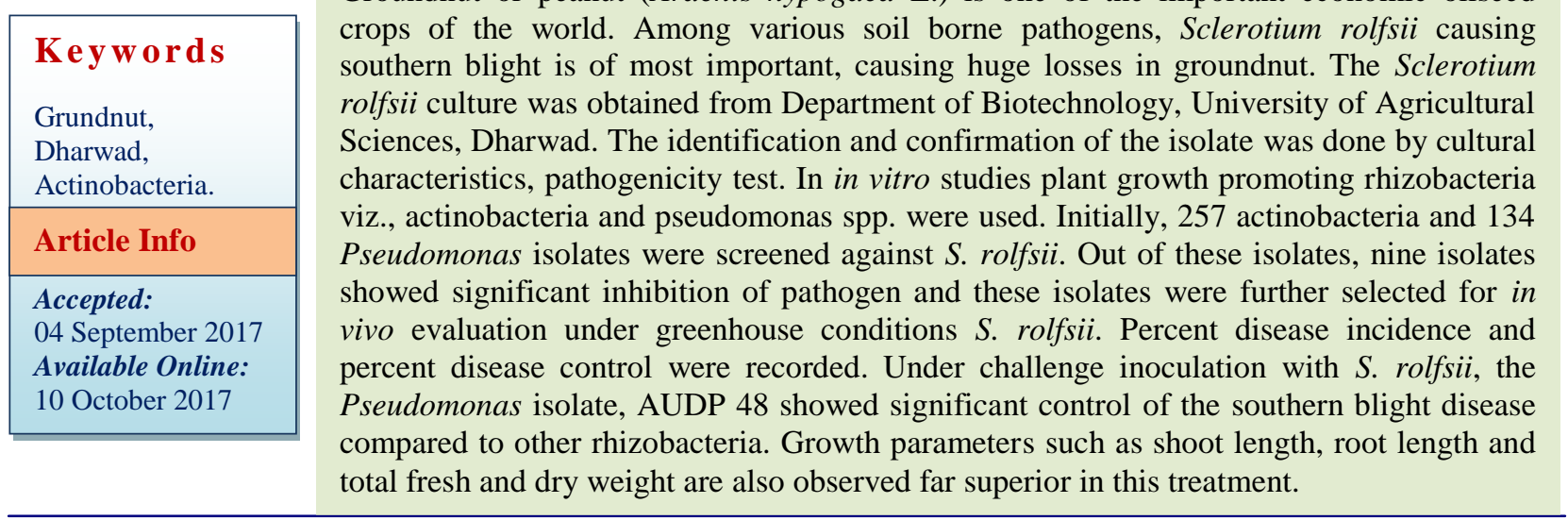

\section{Introduction}

Groundnut or peanut (Arachis hypogaea L.) is one of the important economic oilseed crops of the world. The cultivated groundnut belongs to family Fabaceae, subfamily Papilionaceae. Groundnut is grown in nearly 100 countries. It occupies 21.7 million ha worldwide with a total production of 38.6 million tonnes during 2011 (FAOSTAT, 2011). Among the soil-borne fungal diseases of groundnut, stem rot, also known as southern blight, southern stem rot, sclerotium rot or white mould caused by Sclerotium rolfsii Sacc, is a disease of economic significance throughout the World (Mehan et al., 1994). The pathogen attacks host plant during all growth stages when conditions are favourable (Punja, 1985). Adiver (2003) reported the yield loss of $15-70 \%$ in groundnut is due to leaf spot, rust and stem rot singly or in combination.

The non-pathogenic soil microorganisms involved in enhancing plant resistance and plant growth has been termed as plant growth promoting rhizobacteria (PGPR). Such enhanced state of resistance has been effective against a broad range of pathogens and parasites, including fungi, bacteria, viruses, nematodes, parasitic plants and even insect herbivores along with growth 
promotion in plant (Van Loon et al., 1998; Zehnder et al., 2001). They reduce pathogens as well as biotic or abiotic stresses (Vessey, 2003; Kumar et al., 2014). Among the rhizobacteria, actinobacteria are present extensively in the plant rhizosphere and produce various agro active compounds. In the last few years, this group of bacteria, due to its strong antimicrobial potential, and soil dominant saprophytic nature, gained much attention due to an active colonization in plant root systems, can degrade a wide range of biopolymers by secreting several hydrolytic enzymes and tolerate hostile conditions by forming spores (Alexander, 1977). Actinobacteria, especially Streptomyces, also exhibit immense biocontrol action against a range of phytopathogens (Wang et al., 2013).

Pseudomonas spp received great attention as biocontrol agent because of their catabolic versatility, excellent root-colonizing abilities and production of broad range antifungal (Raaijmaker et al., 2002) Moreover, they produce active extracellular compounds such as siderophores responsible for the biological suppression of several soil borne plant pathogens (Bagnasco et al., 1998). Some Pseudomonas spp. has been shown to initiate the expression of plant defense mechanisms (Curl and Truelove, 1986).

In present study, the effect of actinobacteria and Pseudomonas spp. against Sclerotium rolfsii in Groundnut disease control and plant growth parameters were studied.

\section{Materials and Methods}

\section{Collection, purification and pathogenicity test of Sclerotium rolfsii}

Sclerotium rolfsii culture was obtained from IABT culture collection which was purified on potato dextrose agar (PDA) plates and incubated at $28{ }^{\circ} \mathrm{C}$ for $4-6$ days. Stock culture of $S$. rolfsii was maintained on PDA slants and stored at $4{ }^{\circ} \mathrm{C}$ and spores were stored as glycerol stocks at $-20{ }^{\circ} \mathrm{C}$.

For confirmation of virulence of S.rolfsii, pathogenicity test was conducted. Gaint culture of Sclerotium rolfsii was prepared (Shivakumar, 2007). Sand corn meal medium was used to prepare the giant culture. It was prepared by mixing 95 parts of sand with 5 parts of maize grit. Sand corn meal medium was transferred to autoclavable polythene bags at $500 \mathrm{~g}$ in each bag and sterilized at 15 lbs per sq. inch for 30 minutes.

The sterile medium in the bags was inoculated with fresh culture of Sclerotium rolfsii and incubated at $27 \pm 1^{\circ} \mathrm{C}$ for 30 days. The giant culture with full cottony growth was used in the pot culture experiment (10\% inoculum). Initially inoculated to sterile soil to check pathogenicity in groundnut seeds of two susceptible varieties JL 24 and TMV-2 were used along with control, each with 5 replications. Observations were recorded 15 days after sowing.

Seventy five Pseudomonas fluorescens isolates were isolated from garden soil samples of Kerala. Fifty nine Pseudomonas isolates were obtained from culture collection of Department of Biotechnology, College of Agriculture, Dharwad and a total of One hundred and thirty four Pseudomonas isolates were screened against $S$. rolfsii.

\section{Invitro assay for selection of antagonistic rhizobacteria against Sclerotium rolfsii}

In primary screening, 3 day old $S$. rolfsii agar discs of $5 \mathrm{~mm}$ were placed at center of SCA agar and 257 actinobacteria were screened by streaked on four sides of the discs. 257 actinobacteria were screened against $S$. rolfsii and 36 Actinobacteria showing best inhibition were further selected for secondary screening. In secondary screening (Soares et al., 2006) actinobacteria were streaked at the middle of 
plate containing Soya-Casein Digest Agar Medium (SCBA). Agar plugs of growth of $S$. rolfsii were placed on both sides of the streaked culture after four days using a cork borer. The growth of the pathogen was noted periodically. All isolates are tested in triplicate. The percent of inhibition was calculated by following formula, Inhibition $(\%)=[($ Growth radius in untreated control Growth radius in treatment) $\times 100] /$ Growth radius in untreated control (Taechowisan et al., 2005).

Similarly for in vitro screening, 134 Pseudomonas isolates were screened for potential antagonistic activity against $S$. rolfsii on King's B agar using dual culture technique (Rangeshwaran and Prasad, 2000). An agar disc (5 mm dia.) was cut from an actively growing (96 hr) $S$. rolfsii culture and placed on the surface of fresh King's B agar medium at the one side of the Petri plates. A loopful of actively growing Pseudomonas isolates (each) was placed opposite to the fungal disc. Plates inoculated with $S$. rolfsii and without bacteria were used as control. Each experiment was carried out in triplicates and repeated thrice. Plates were incubated at room temperature for 7 days. Degree of antagonism was determined by measuring the radial growth of pathogen with bacterial culture and control and percentage inhibition calculated by the following equation (Riungu et al., 2008).

Inhibition $\%=$ Colony diameter of Pathogen alone (Control) - Colony diameter of Pathogen + Antagonist x 100/Colony diameter of Pathogen alone

In vivo screening of rhizobacterias against $S$. rolfsii in groundnut

Based on in vitro assay 5 actinobacteria and 4 Pseudomonas isolates were selected for in vivo assays along with 2 reference actinobacteria strains (AUDT 217, AUDT 248) and one Pseudomonas reference strain
(AUDP 1) were also included in the experiment.

\section{Preparation of $S$. rolfsii inoculum}

Giant culture prepared in sand corn meal medium (Abeyagunawrdena and Wood, 1957) was used for in vivo experiments (as previously mentioned pathogenicity test) in pot experiment, all the treatments except absolute control were added with giant culture of $10 \% \mathrm{w} / \mathrm{w}$ of soil per pot. Water was added to each plastic cup to wet the potting mixture (soils and 2:1) and the cups were covered with polythene sheets for developing high humidity. The whole set-up was incubated at $32 \pm 2{ }^{\circ} \mathrm{C}$ in green house for multiplication of pathogen and allowed for multiplication for 2 weeks.

\section{Method of application of the rhizobacterial isolates}

The method of application of isolates to plants consisted of seed priming, soil application and foliar application.

\section{Seed priming}

Groundnut and Brinjal seeds were surface sterilized with $0.02 \%$ mercuric chloride for 5 min and rinsed thoroughly in sterile water. The rhizobacterial cultures were grown on broth viz., actinobacteria (1wk) and Pseudomonas (24hr). The cfu of the culture was adjusted to $1 \times 10^{8} / \mathrm{ml}$.

The priming of the seed was done by soaking seeds in grown cultures of actinobacteria and Pseudomonas isolates separately and with 1 $\%$ sterilized carboxy methyl cellulose (CMC) as a sticker. The suspensions were incubated for 10 min to facilitate attachment of bacterial cells to the seed coat. Later, the seed were allowed to dry (Ramanathan et al., 2000). Dried seed were sown to pots containing sterile soil. 
Preparation and application of the lignite based culture

The lignite based culture was prepared by mixing the cultures of isolates with sterile lignite in 1:3 ratios and soil application was done at rate of $100 \mathrm{mg}$ of lignite base culture/Kg of soil (Ramamoorthy et al., 2002). Foliar application was performed with $2 \%$ lignite based culture at fifteen days interval i.e. 15, 30 after sowing (DAS) (Bahadur et al., 2007).

\section{Monitoring of the disease}

All the inoculated plants were observed regularly for symptoms (wilting, yellowing of the entire leaves or only the lower leaves, occurrence of the lesions and crown infection) were evaluated and the development of disease for about month. After one month of inoculation, the per cent disease incidence (PDI) was calculated by using following formula (Mahato et al., 2014)

Per cent disease Incidence $(\mathrm{PDI})=$ Number of plants infected

$\mathrm{x} 100$

Total number of plants observed

Disease incidence was determined when all plants show death symptoms in only pathogen inoculated treatment or after 1 month of the treatment. The observation on the per cent disease reduction (\% DIR) was calculated by using the formula given below (Mahato et al., 2014).

$\%$ DIR $=$ No. of plants infected in control No. of plants infected in treatment $x$ 100/No. of plants infected in control

\section{Evaluation of effect of rhizobacteria on plant growth parameters}

Growth parameters including shoot and root length, fresh and dry weight of shoot and root, number of branches, root and shoot dry weight were determined at day 30 after inoculation or when all plants die in pathogen control. The dry matter content of the plants was recorded after drying the plants to constant weight at $60^{\circ} \mathrm{C}$. These biometric observations were recorded from the ten plants per treatment. The mean often plant's observation were considered for statistical analysis. The experiments were repeated in triplicates (Gopalakrishnan et al., 2011). There were 14 treatments with 10 replications each.

\section{Results and Discussion}

\section{Purification and pathogenicity test of $S$. rolfsii}

The Sclerotium rolfsii culture was obtained from the culture collection of department of Biotechnology, College of Agriculture, Dharwad. The culture was purified on PDA media and after incubation for $48-72 \mathrm{~h}$ at $28^{\circ}$ $\mathrm{C}$, typical white cottony mycelium (Plate 1) was observed. On further incubation mustard seed like sclerotial bodies was observed. For the pathogenicity test of $S$. rolfsii soil inoculation method was followed. The two susceptible varieties JL 24 and TMV-2 were used for pathogenicity test. JL 24 was found to be more susceptible to $S$. rolfsii showing high inhibition of germination by the pathogen while in uninoculated control pots cent per cent seed germination and good growth of the seedlings was observed (Plate 2). The symptoms of stem rot characterized by yellowing of groundnut leaves followed by loss of vigor were observed. JL 24 was used for in vivo pot experiments.

\section{Antimicrobial activity of the rhizobacterial isolates against $S$. rolfsii}

Out of 257 isolates of actinobacteria screened, 36 isolates were found to be inhibiting $S$. rolfsii after primary screening and after 
secondary screening, five isolates were more potent. The details are presented in table 1 . Among five actinobacterias, AUDT 294 was most potent and showed $83.37 \%$ inhibition of S. rolfsii followed by AUDT $502(64.16 \%)$ and AUDT $626(64.15 \%)$ AUDT 576 (62.94\%) and AUDT 673 (58.23\%). These five potent isolates were used for in vivo assays (Plate 3). A total of One hundred and thirty four Pseudomonas isolates were screened against $S$. rolfsii. Among them nineteen isolates were highly inhibiting and appeared significantly different in their inhibition against $S$. rolfsii, 4 isolates among showed high inhibition of $S$. rolfsii (Table 1). AUDP 48 was the most potent isolate showing $100 \%$ inhibition of pathogen followed by AUDP 276 (63\%), AUDP 15(59\%), AUDP 237 (55\%). These isolates were further used for in vivo pot experiments (Plate 3).

In vivo screening of rhizobacterias against $S$. rolfsii in groundnut

\section{Effect of inoculation on $S$. rolfsii disease development}

Seven actinoacteria and five Pseudomonas isolates were tested for their ability to $S$. rolfsii. A wide range of response of groundnut plants to the inoculation of the test isolates against $S$. rolfsii was noticed (Table 2). The disease symptoms include stunting, poor growth and rotting at the collar region which could be easily pulled out of the soil and wilting and death of plants later. The number of plants with disease symptoms was significantly lower in treatments that received the rhizobacteria when compared to the disease control (Plate 4). Among the test isolates, Pseudomonas isolate AUDP 48 was more effective in control of disease $(60 \%$ disease incidence and $33.33 \%$ disease reduction) followed by AUDT 217 (70\% disease incidence and $22.22 \%$ disease reduction) while four actinobacteria isolates viz., AUDT 502, AUDT 576, AUDT 673, AUDT 248 and two Pseudomonas isolates AUDP 276 and AUDP 237 showed similar results $(80 \%$ disease incidence and $11.11 \%$ disease reduction) (Table 2). Hence isolate AUDP 48 was regarded as most effective in control of $S$. rolfsii in groundnut.

\section{Evaluation of the effect of rhizobacteria on plant growth parameters of groundnut}

\section{Shoot length}

At 30 days after inoculation of pathogen (DAI), the significant increase in shoot length over control was observed due to inoculation of selected rhizobacterial isolates which ranged from 7.7 to $34.57 \mathrm{~cm} \mathrm{~cm}$ whereas it was $7.7 \mathrm{~cm}$ in disease control and $25.31 \mathrm{~cm}$ in healthy control (Table 3, Plate 5). The maximum shoot length was observed in plants inoculated with AUDP $48(34.57 \mathrm{~cm})$, which was followed by AUDT502 $(26.6 \mathrm{~cm})$ and AUDT217 $(26.55 \mathrm{~cm})$. There were no negative effects of inoculation on plants shoot length compared to disease control. The least shoot length was observed in treatment which was challenged with $S$. rolfsii and not inoculated with any rhizobacteria $(7.7 \mathrm{~cm})$. AUDP 48 increased the shoot length by $26.87 \mathrm{~cm}$ over the disease control and by $9.26 \mathrm{~cm}$ over the healthy control.

\section{Shoot fresh weight}

The shoot fresh weight was recorded at 30 DAI. The data pertaining to influence of different treatments on shoot dry matter content of plants is furnished in table 3 . The fresh weight of the plants inoculated with test isolates ranged between $0.46 \mathrm{~g}$ per plant to $3.413 \mathrm{~g}$ per plant. AUDP 48showed the highest fresh weight which was $3.413 \mathrm{~g}$ per plant which was followed by plant inoculated with AUDT217 (2.105g) and AUDP 276 (2.01g) treated. In control, it was $1.54 \mathrm{~g}$ and in pathogen control it was $0.36 \mathrm{~g}$. The 
inoculation of AUDP 48increased the shoot fresh weight by $3.053 \mathrm{~g}$ over the disease control and by $1.873 \mathrm{~g}$ over the healthy control.

\section{Shoot dry weight}

The observations on the influence of rhizobacterial inoculation on dry weight of the groundnut plants were recorded at 30DAI and data is presented in table 5. The dry weight of the plants in rhizobacteria inoculated treatment ranged from $0.071 \mathrm{~g}$ to $0.738 \mathrm{~g}$. The isolates viz., AUDP48 $(0.738 \mathrm{~g})$, AUDP $276(0.483 \mathrm{~g})$ and AUDP $15(0.32 \mathrm{~g})$ showed significant increase in shoot dry weight among all of the inoculated isolates than control $(0.236 \mathrm{~g})$ and pathogen control $(0.103 \mathrm{~g})$ plants. The inoculation of AUDP 48increased the shoot dry weight by $0.635 \mathrm{~g}$ over the disease control and by $0.502 \mathrm{~g}$ over the healthy control.

\section{Number of branches}

At 30 DAI the observations on number of branches were recorded (Table 3 ) and it was found that in rhizobacteria treated plants the number of branches ranged between 2 to7.33. The highest number of branches were noticed in isolate AUDP 48 treated plants (7) followed by AUDT 673 and AUDP 237 of 6 branches. In control it was 5 and in pathogen control it was 2 branches.

\section{Root length}

The root length of groundnut plants significantly differed at $30 \mathrm{DAI}$ of plant due to various inoculation treatments. The data are presented in table 4 . The root length of plants inoculated with test isolates ranged from 1.16 to $11.85 \mathrm{~cm}$. It was $1.26 \mathrm{~cm}$ in disease control and $9.03 \mathrm{~cm}$ in healthy control. The maximum root length was seen in inoculation of AUDT
$673(11.85 \mathrm{~cm})$ which showed an increase over disease control by $10.66 \mathrm{~cm}$ and by 8.21 $\mathrm{cm}$ over healthy control. Other isolates like AUDP $48(11.47 \mathrm{~cm})$ and AUD $248(11 \mathrm{~cm})$ also showed significant increase in root length when compared with both disease and healthy controls (Plate 5).

\section{Root fresh weight}

The root fresh weight was recorded at 30 DAI. The data pertaining to influence of different treatments on shoot dry matter content of plants is furnished in table 4. The fresh weight of the plants inoculated with test isolates ranged between $0.08 \mathrm{~g}$ to $0.825 \mathrm{~g}$ per plant. AUDP 276 showed the highest fresh weight which was $0.825 \mathrm{~g}$ which was followed by plant inoculated with AUDP $15(0.71 \mathrm{~g})$ and AUDP $48(0.637 \mathrm{~g})$ treated. In control, it was $0.324 \mathrm{~g}$ and in pathogen control it was $0.09 \mathrm{~g}$. The inoculation of AUDP 276 increased the root fresh weight by $0.735 \mathrm{~g}$ over the disease control and by $0.501 \mathrm{~g}$ over the healthy control.

\section{Root dry weight}

The root dry weight was recorded at 30 DAI. The data pertaining to influence of different treatment on root dry matter content of plants is furnished in table 4 . The root dry weight of plant treated with selected twelve isolates ranged from $13 \mathrm{mg}$ to $142 \mathrm{mg}$ after $30 \mathrm{DAI}$ and it was $17.7 \mathrm{mg}$ in disease control and 89.6 $\mathrm{mg}$ in healthy control. The application of AUDP 276 resulted in the maximum increase in root dry weight which was $142 \mathrm{mg}$ an increase of $124.3 \mathrm{mg}$ over disease control and by $52.4 \mathrm{mg}$ over healthy control. Other isolates which improved root dry weight include AUDP 48 (137 mg), AUDP15 (133 $\mathrm{mg})$ and AUDP $1(120 \mathrm{mg})$ also showed significant increase in root dry weight in inoculated groundnut plants (Plate 5). 
The treatments were as follows

\begin{tabular}{|l|l|}
\hline Treatments & Treatment Details \\
\hline T1 & No rhizobacteria, no S. rolfsii (Healthy Control) \\
\hline T2 & No rhizobacteria + S. rolfsii (Disease control) \\
\hline T3 & AUDT $294+S$. rolfsii \\
\hline T4 & AUDT502+ S. rolfsii \\
\hline T5 & AUDT $626+$ S. rolfsii \\
\hline T6 & AUDT $576+$ S. rolfsii \\
\hline T7 & AUDT $673+S$. rolfsii \\
\hline T8 & AUDT $248+S$. rolfsii \\
\hline T9 & AUDT $217+S$. rolfsii \\
\hline T10 & AUDP $48+S$. rolfsii \\
\hline T11 & AUDP $276+S$. rolfsii \\
\hline T12 & AUDP $15+S$. rolfsii \\
\hline T13 & AUDP $237+S$. rolfsii \\
\hline T14 & AUDP $1+S$. rolfsii \\
\hline
\end{tabular}

Table.1 Per cent Inhibition of S. rolfsii by rhizobacteria isolates

\begin{tabular}{|l|l|c|}
\hline Sl No & $\begin{array}{l}\text { Rhizobacterial } \\
\text { Isolates }\end{array}$ & \% Inhibition \\
\hline 1 & AUDT 294 & 83.37 \\
\hline 2 & AUDT 502 & 64.16 \\
\hline 3 & AUDT 626 & 64.15 \\
\hline 4 & AUDT 576 & 62.98 \\
\hline 5 & AUDT 673 & 58.23 \\
\hline 6 & AUDT 217 & 52.94 \\
\hline 7 & AUDT248 & 47.06 \\
\hline 8 & AUDP 48 & 100 \\
\hline 9 & AUDP 276 & 62.94 \\
\hline 10 & AUDP 15 & 58.82 \\
\hline 11 & AUDP 237 & 54.7 \\
\hline 12 & AUDP 1 & 39.41 \\
\hline SE $(\mathrm{m}) \pm$ & 2.69 \\
\hline CD at 5\% & 7.86 \\
\hline
\end{tabular}


Table.2 Per cent disease incidence in groundnut plants inoculated with rhizobacterias in response to $S$. rolfsii inoculation

\begin{tabular}{|l|l|l|l|}
\hline $\begin{array}{l}\text { Sl } \\
\text { No }\end{array}$ & Treatments & $\begin{array}{l}\text { Percent disease } \\
\text { incidence } \\
\text { 30 DAI }\end{array}$ & $\begin{array}{l}\text { \% Disease } \\
\text { reduction } \\
\text { 30 DAI }\end{array}$ \\
\hline T1 & No rhizobacteria, no S. rolfsii (Healthy Control) & 0 & - \\
\hline T2 & No rhizobacteria + S. rolfsii (Disease control) & 90 & - \\
\hline T3 & AUDT 294+S. rolfsii & 90 & 0 \\
\hline T4 & AUDT502+ S. rolfsii & 80 & 11.11 \\
\hline T5 & AUDT $626+$ S. rolfsii & 90 & 0 \\
\hline T6 & AUDT 576+ S. rolfsii & 80 & 11.11 \\
\hline T7 & AUDT $673+$ S. rolfsii & 80 & 11.11 \\
\hline T8 & AUDT 248+ S. rolfsii & 80 & 11.11 \\
\hline T9 & AUDT 217+ S. rolfsii & 70 & 22.22 \\
\hline T10 & AUDP $48+$ S. rolfsii & 60 & 33.33 \\
\hline T11 & AUDP 276+ S. rolfsii & 80 & 11.11 \\
\hline T12 & AUDP 15+ S. rolfsii & 90 & 0 \\
\hline T13 & AUDP 237+ S. rolfsii & 80 & 11.11 \\
\hline T14 & AUDP $1+$ S. rolfsii & 90 & 0 \\
\hline
\end{tabular}

DAI Days after inoculation of Pathogen

Table.3 Plant growth parameters as influenced by rhizobacteria inoculation in groundnut (30 DAI of $S$. rolfsii) under greenhouse condition

\begin{tabular}{|l|l|l|l|l|l|}
\hline Treatments & $\begin{array}{l}\text { Treatment } \\
\text { Details }\end{array}$ & $\begin{array}{l}\text { Shoot } \\
\text { Length } \\
\text { (cm) }\end{array}$ & $\begin{array}{l}\text { Shoot } \\
\text { Fresh } \\
\text { weight }(\mathbf{g})\end{array}$ & $\begin{array}{l}\text { Shoot dry } \\
\text { weight }(\mathbf{g})\end{array}$ & $\begin{array}{l}\text { No. of } \\
\text { branches }\end{array}$ \\
\hline T1 & No rhizobacteria, no S. rolfsii (Healthy Control) & 25.31 & 1.54 & 0.236 & 5 \\
\hline T2 & No rhizobacteria + S. rolfsii (Disease control) & 7.7 & 0.36 & 0.103 & 2 \\
\hline T3 & AUDT 294+S. rolfsii & 7.8 & 0.252 & 0.093 & 2 \\
\hline T4 & AUDT502+ S. rolfsii & 26.6 & 1.28 & 0.203 & 5 \\
\hline T5 & AUDT 626+ S. rolfsii & 7.7 & 0.253 & 0.094 & 2 \\
\hline T6 & AUDT 576+ S. rolfsii & 12.6 & 0.46 & 0.071 & 3 \\
\hline T7 & AUDT 673+ S. rolfsii & 26.1 & 1.935 & 0.296 & 6 \\
\hline T8 & AUDT 248+ S. rolfsii & 22.05 & 1.73 & 0.258 & 6 \\
\hline T9 & AUDT 217+ S. rolfsii & 26.55 & 2.105 & 0.231 & 6 \\
\hline T10 & AUDP 48+ S. rolfsii & 34.57 & 3.413 & 0.738 & 7 \\
\hline T11 & AUDP 276+ S. rolfsii & 24.5 & 2.01 & 0.483 & 5 \\
\hline T12 & AUDP 15+ S. rolfsii & 25.53 & 1.87 & 0.32 & 6 \\
\hline T13 & AUDP 237+ S. rolfsii & 13.5 & 0.815 & 0.128 & 6 \\
\hline T14 & AUDP 1+ S. rolfsii & 13.23 & 0.73 & 0.17 & 5 \\
\hline & S.Em \pm & 2.644 & 0.352 & 0.08 & 0.97 \\
\hline & CD (at 5\%) & 7.66 & 1.02 & 0.232 & 2.81 \\
\hline
\end{tabular}

DAI Days after inoculation of Pathogen 
Table.4 Plant growth parameters as influenced by rhizobacterias inoculation in groundnut 30 DAI of S.rolfsii under greenhouse condition

\begin{tabular}{|c|c|c|c|c|}
\hline Treatments & $\begin{array}{l}\text { Treatment } \\
\text { details }\end{array}$ & $\begin{array}{l}\text { Root } \\
\text { Length } \\
\text { (cm) }\end{array}$ & $\begin{array}{l}\text { Root } \\
\text { Fresh } \\
\text { weight (g) }\end{array}$ & $\begin{array}{l}\text { Root dry } \\
\text { weight } \\
\text { (mg) }\end{array}$ \\
\hline $\mathrm{T} 1$ & $\begin{array}{l}\text { No rhizobacteria, no } S \text {. } \\
\text { rolfsii (Healthy Control) }\end{array}$ & 9.03 & 0.324 & 89.6 \\
\hline $\mathrm{T} 2$ & $\begin{array}{l}\text { No rhizobacteria }+S \text {. } \\
\text { rolfsii (Disease control) }\end{array}$ & 1.19 & 0.09 & 17.7 \\
\hline $\mathrm{T} 3$ & AUDT 294+S. rolfsii & 1.35 & 0.063 & 16 \\
\hline $\mathrm{T} 4$ & AUDT502+ S. rolfsii & 8.05 & 0.405 & 40 \\
\hline T5 & AUDT $626+S$. rolfsii & 1.16 & 0.08 & 13 \\
\hline T6 & AUDT $576+$ S. rolfsii & 8.15 & 0.325 & 46 \\
\hline $\mathrm{T} 7$ & AUDT $673+S$. rolfsii & 11.85 & 0.235 & 47 \\
\hline $\mathrm{T} 8$ & AUDT $248+S$. rolfsii & 11 & 0.34 & 56 \\
\hline T9 & AUDT $217+$ S. rolfsii & 10.05 & 0.395 & 75 \\
\hline T10 & AUDP $48+S$. rolfsii & 11.47 & 0.637 & 137 \\
\hline T11 & AUDP 276+ S. rolfsii & 9.25 & 0.825 & 142 \\
\hline $\mathrm{T} 12$ & AUDP $15+S$. rolfsii & 4.2 & 0.71 & 133 \\
\hline T13 & AUDP $237+S$. rolfsii & 4.6 & 0.48 & 105 \\
\hline \multirow[t]{3}{*}{$\mathrm{T} 14$} & AUDP $1+S$. rolfsii & 9.5 & 0.25 & 12 \\
\hline & S.Em \pm & 1.969 & 0.083 & 0.025 \\
\hline & $\mathrm{CD}($ at $5 \%$ ) & 5.705 & 0.24 & 0.074 \\
\hline
\end{tabular}

DAI Days after inoculation of Pathogen

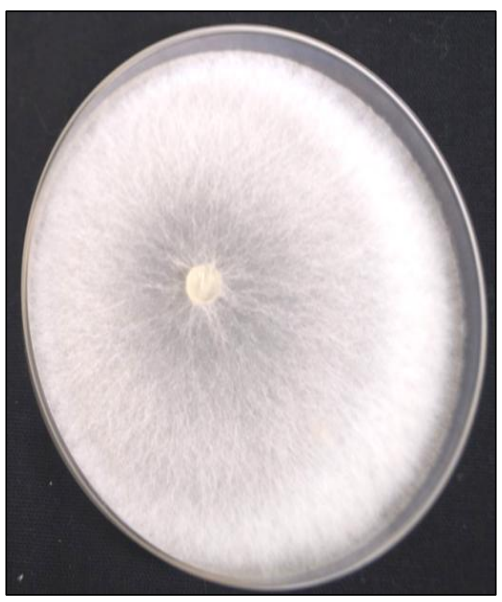

Plate 1: Mycelial growth of Scleotium rolfsii on PDA media

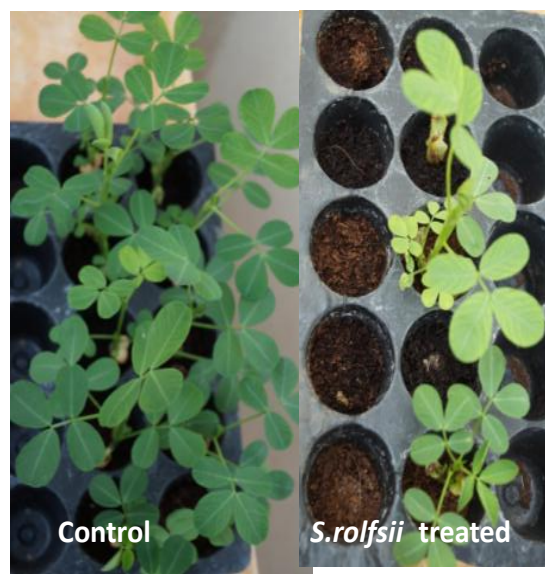

Plate 2: Pathogenicity test for S.rolfsii on groundnut 


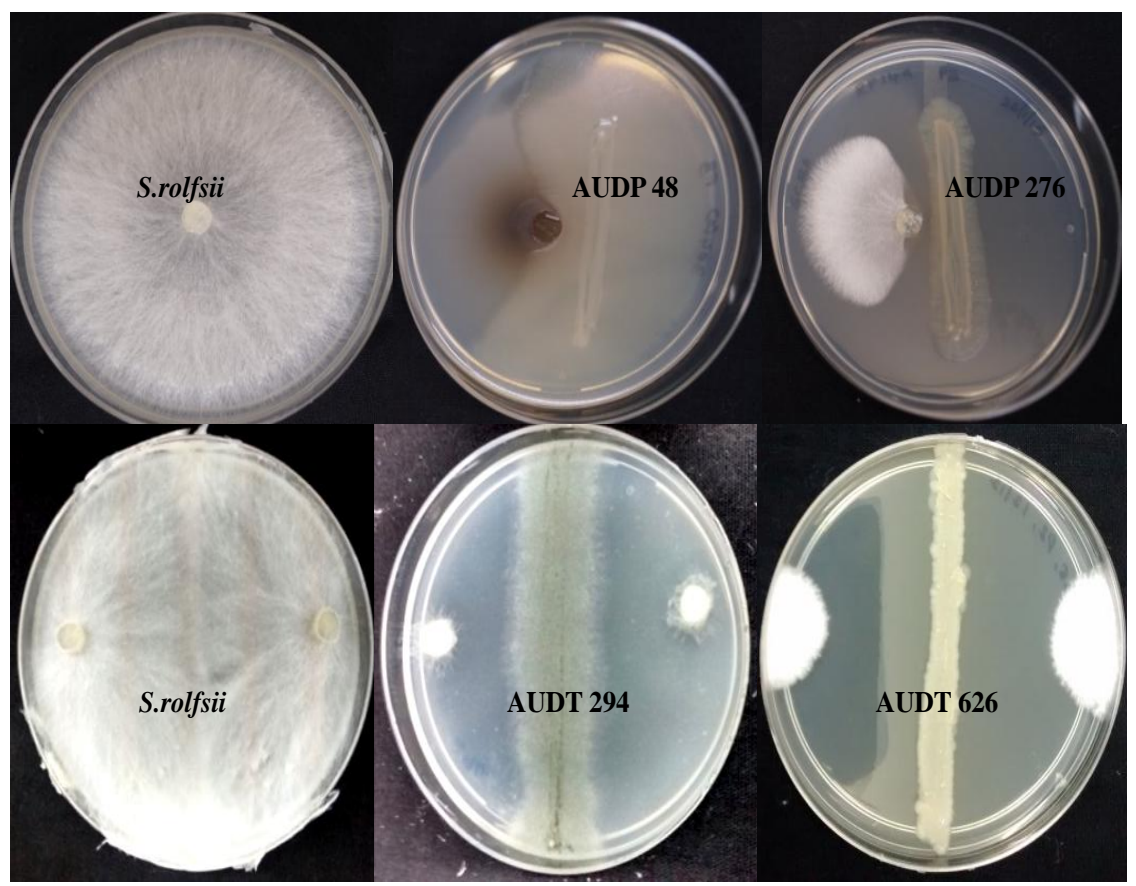

Plate 3: \% Inhibition of S.rolfsii by rhizobacteria isolates
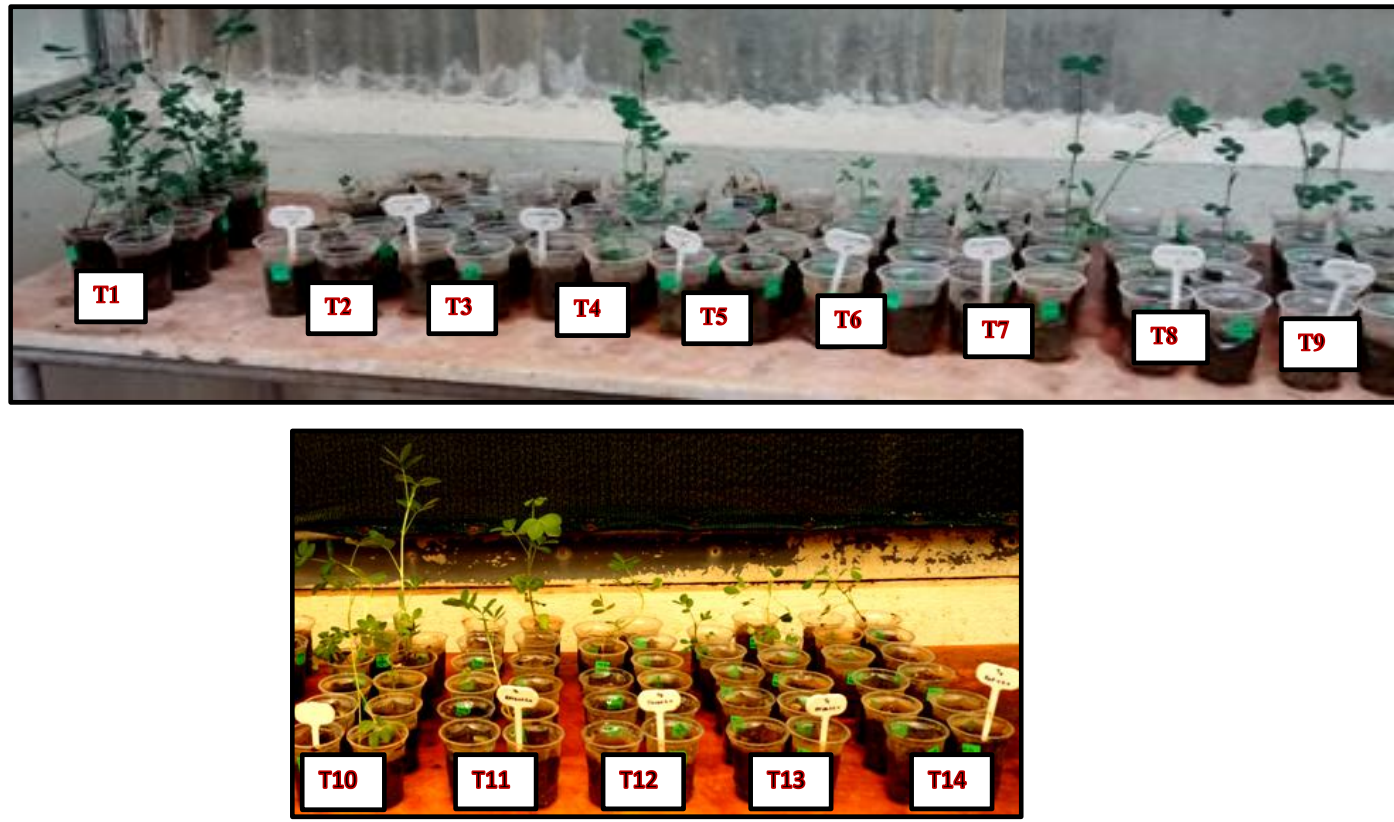

Plate 4: Comparision between different treatments of rhizobacterias for disease control of S.rolfsii in groundnut 


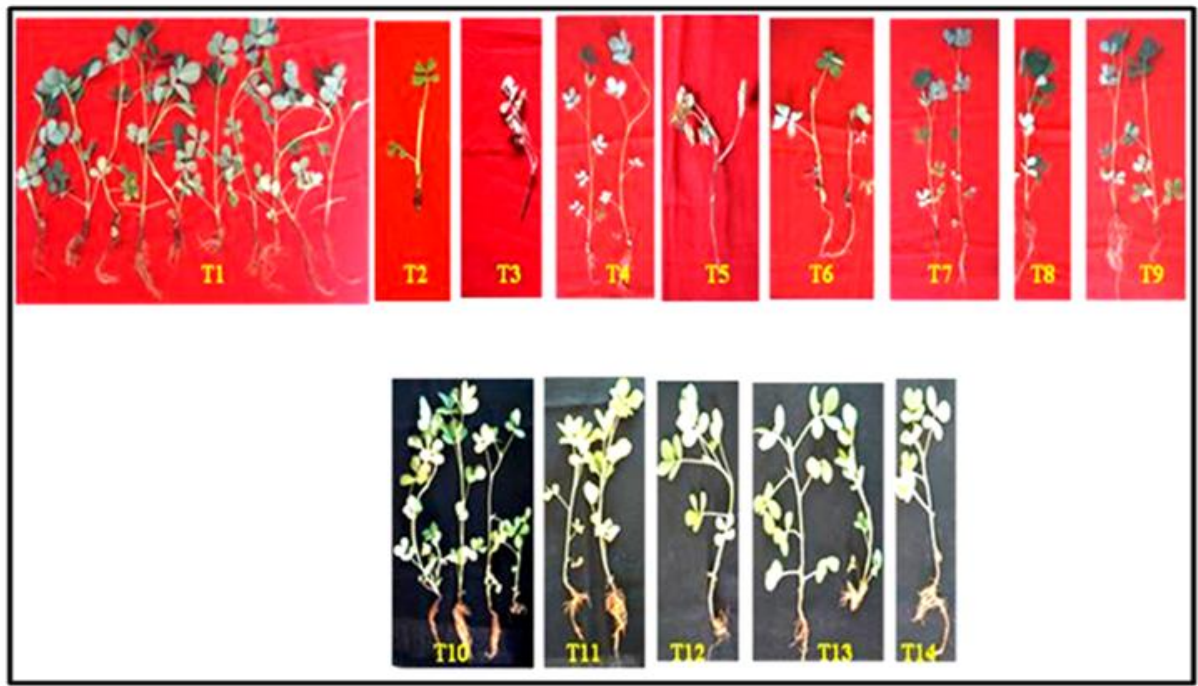

Plate.5: Comparision between different treatments of rhizobacteria with challenge inoculation of $S$.rolfsii in groundnut growth parameters

Soil borne pathogens or root pathogens are considered to be one of the major problems in agricultural production throughout the world, causing reduction in yield and quality of crops. The most deleterious diseases in recent years are Southern blight caused by Sclerotium rolfsii Sacc. in groundnut. Chemical management is often too expensive, exposure risks, residue persistence, causing health and environmental hazards and not feasible because these pathogens are soilborne. The persistence of the pathogen in soil and wide host range often limits the effectiveness of chemical and cultural control of stem and pod rot. In this context, biological control can be an alternative of or supplement to current management practices for $S$. rolfsii (Dey et al., 2004; Tonelli et al., 2010). The experiment was conducted to study the interaction of rhizobacteria in controlling $S$. rolfsii which is discussed here.

\section{Purification, pathogenicity test and} confirmation of $S$. rolfsii

In present study, the Sclerotium rolfsii culture was collected from IABT culture collection and purified on PDA media, after incubation for $48-72 \mathrm{~h}$ at $28^{0} \mathrm{C}$. The fungus is characterized by white mycelia, and round, brown sclerotia, which range from $0.5-2 \mathrm{~mm}$ in diameter. The colony morphology was in similar to that observed by Punja (1985).

The pathogenicity test conducted using two susceptible groundnut varieties JL 24 and TMV 2. The symptoms of low germination, yellowing, stunting, wilting was noticed in both the treatments with JL 24 showing high disease severity plants indicating their susceptible nature.

Hence virulence of parthogen was confirmed and the results were in agreement with the previous work conducted by Ingale and Mayee (1986) where S. rolfsii caused 25 per cent of seedling mortality in the cultivar JL24 of groundnut. Soil inoculation method of pathogenicity test was confirmed by Doley and Jite (2013); Biswas and Sen (2000) and Anahosur (2001). On the basis of morphological and cultural characteristics and pathogenicity, test the pathogens were confirmed as Sclerotium rolfsii. 
Antimicrobial activity of the rhizobacterial isolates against $S$. rolfsii

The current study was undertaken to identify effective isolates in vitro. The primary screening was carried out using cross streak method for 257 actinobacteria isolates and 134 Pseudomonas isolates against the test pathogen, S. rolfsii. Of all the tested isolates, 36 actinobacteria isolates showed inhibition effect to $S$. rolfsii and in secondary screening of these isolates, 5 isolates viz., AUDT 294, AUDT 502, AUDT 626, AUDT 576, AUDT 673 showed highest inhibitory activity against the $S$. rolfsii. Among Pseudomonas isolates tested, four isolates viz., AUDP 48, AUDP 276, AUDP 15 and AUDP 237 were most effective in inhibiting $S$. rolfsii. Pseudomonas Isolate AUDP 48 showed highest inhibition of $100 \%$ as compared to all rhizobacteria tested. The result were in agreement with the previous work conducted by Ganesan and Sekar et al., (2012) who reported that Pseudomonas isolate PIS9 showed an inhibition of $77.61 \%$ in dual culture assay against $S$. rolfsii. In similar stream of efforts, Chanutsa et al., (2014) the most effective isolate (KK11EBa-3) was identified as Pseudomonas aeruginosa inhibited S. rolfsii by $60 \%$. Similarly, Rakh et al., (2011) revealed that Pseudomonas culture CA/RN was able to inhibit Sclerotium rolfsii (94\%). In the results earlier reported by Kishore et al., (2005), for control of S. rolfsii with Pseudomonas aeruginosa in dual culture there was only 32-74\% inhibition recorded against $S$. rolfsii. It was found that our results with Pseudomonas AUDT 48 are far better than the above mentioned previous results. The possible reasons for the inhibition of $S$. rolfsii could be due to Pseudomonas spp. produces a wide range of antifungal compounds i.e., fluorescent pigments siderophores, volatile compounds such as $\mathrm{HCN}$, antibiotics such as phenazine-1-carboxylic acid, pyoluteorin phenazine-1-carboxamide, viscosinamide and tesin and lytic enzymes. The phenolic metabolite 2, 4-DAPG is an important component of the natural suppressiveness of pathogens in soil.

\section{In vivo screening of rhizobacterias against $S$. rolfsii in groundnut}

Presently, greater emphasis has been replaced with biological control, in order to reduce the environmental hazards, to avoid the development of resistant strains and to reduce the cost of cultivation (Deepthi and Reddy, 2013). Actinobactria and Pseudomonas are capable of ensuring the defense of the plants against phytopathogenic fungi and bacteria. Successful control of disease caused by $S$. rolfsii by application of fungal and bacterial biological agents to the soil has been reported by several workers (Asghari and Mayee, 1990; Ristaino et al., 1991; Muthamilan and Jayarajan, 1996; Ganesan, 2004; Ganesan and Sekar, 2011).

Some Pseudomonas species and strains to control stem rot disease of groundnut caused by S. rolfsii (Ganesan and Gnanamanickam 1987; Tonelli et al., 2011).

The present study aimed to identify potent rhizobacteria which can suppress the southern blight pathogen caused $S$. rolfsii in groundnut and also have growth promotion activities.

\section{Effect of rhizobacteria inoculation on $S$. rolfsii disease development}

In present investigation, seven actinoacteria and five Pseudomonas isolates were tested for their ability to inhibit $S$. rolfsii under greenhouse conditions along with three reference isolates. A wide range of response of groundnut plants to the inoculation of the test isolates against $S$. rolfsii was observed. Among all the test isolates, Pseudomonas isolate AUDP 48 was more efficient $(60 \%$ 
disease incidence and $33.33 \%$ disease reduction) followed by AUDT 217 (70\% disease incidence and $22.22 \%$ disease reduction) besides these two isolates, rest of the isolates did not show better control of the pathogen. The results were in agreement with the previous results of Rakh et al., (2011) where the percent disease control due to Pseudomonas cf. monteilii 9 treated seeds compared to the untreated check (Positive control), was found in range of 45.45 to 66.67 $\%$ than positive control. Another work of Kishore et al., 2005 where groundnut seed endophytes Pseudomonas aeruginosa GSE 18 and GSE 19 reduced the seedling mortality by $54 \%$ and $58 \%$, compared to the control. Our result revealed that significant reduction in pathogen inoculum in AUDP48 treated groundnut plants when compared with positive control plants.

\section{Evaluation of effect of rhizobacteria on plant growth parameters of groundnut}

The plant-associated bacteria are classified into three broad groups viz., beneficial, deleterious and neutral, based on their effects on plant growth (Dobbelaere et al., 2003). Wide varieties of soil bacteria have been identified for their beneficial effects on plant and classified as plant growth-promoting rhizobacteria (PGPR) (Kloepper et al., 1999). PGPR grow in association with a host plant results in stimulation of growth in host through different mechanisms.

In present investigation, out of 14 treatments, four Pseudomonas isolates AUDP48, AUDP276, AUDP15, and AUDP237 and two actinobacteria isolates AUDT673, AUDT217 contributed significantly to the improvement of plant growth parameters like, shoot length, shoot fresh weight, root length, shoot dry weight, root dry weight in groundnut at 30 DAI. The application of the test isolates resulted in the observation of promotion of all tested plant growth parameters. The increase in shoot length of plant inoculated with selected isolates ranged from 7.7 to $34.57 \mathrm{~cm}$ after 30 DAI, whereas it was $7.7 \mathrm{~cm}$ in pathogen control.

The inoculation of AUDP48 increased the shoot length by $348.96 \%$ over disease control. Besides AUDP48, other isolates like AUDT502 (245.45 \%) and AUDT217 (244.8 $\%)$ showed significant increase in shoot length in inoculated plants than disease control $(7.7 \mathrm{~cm})$. The root length of plant inoculated with test isolates ranged from 1.16 to $11.85 \mathrm{~cm}$ after 30 DAI. It was $1.19 \mathrm{~cm}$ in disease control. The inoculation of AUDT 673 which showed an increase over disease control by $895.8 \%$. Other isolates like AUDP48 (844.9 \%) and AUDT248 (824.4\%) also showed significant increase in root length 10.21 and $9.74 \mathrm{~cm}$ respectively when compared with disease controls.

The shoot fresh weight of plant inoculated with test isolates ranged between 0.46 to $3.413 \mathrm{~g}$ per plant. The inoculation of AUDP48 (3.413g) which showed increased shoot fresh weight of $3.053 \mathrm{~g}$ over the disease control. Besides AUDP 48 the inoculation of isolates AUDT217 (2.105 g) and AUDP 276 (2.01g) showed an increase in shoot fresh weight of 1.745 and $1.65 \mathrm{~g}$ respectively over disease control. In case of shoot dry weight due to inoculation of test isolates the dry weight of the groundnut plants ranged from $0.071 \mathrm{~g}$ to $0.738 \mathrm{~g}$. The isolates viz., AUDP48 $(0.738 \mathrm{~g})$, AUDP $276(0.483 \mathrm{~g})$ and AUDP15 $(0.32 \mathrm{~g})$ showed significant increase in shoot dry weight among all of the inoculated rhizobacteria than pathogen control $(0.103 \mathrm{~g})$ plants. The inoculation of AUDP48 increased the shoot dry weight by $616.5 \%$ over the disease control. The inoculation of AUDP 276 and AUDP 15 showed an increase in shoot dry weight of 368.9 and $210.7 \%$ over disease control. 
The root fresh weight also showed a significant improvement due to inoculation of rhizobacteria in groundnut plants at $30 \mathrm{DAI}$. The root fresh weight of ranged between 0.08 to $0.825 \mathrm{~g}$ per plant while in disease control it was $0.09 \mathrm{~g}$. The inoculation of AUDP 276 $(0.825 \mathrm{~g})$ showed the maximum root fresh weight and an increase of $816.7 \%$ over the disease control followed by two isolates inoculated with AUDP 15(688.9\%) and AUDP $48(607.7 \%)$. The root dry weight of groundnut plant ranged from $13 \mathrm{mg}$ to 142 $\mathrm{mg}$ at $30 \mathrm{DAI}$ and $17.7 \mathrm{mg}$ in disease control. The maximum dry weight was in AUDP 276 $(142 \mathrm{mg})$ treated plants with an increase of $702.3 \%$ over disease control. Other isolates include AUDP 48 (674 \%), AUDP15 (651.4 $\%$ ) also resulted in significant increase in root dry weight in inoculated groundnut plants. The number of branches in the rhizobacteria treated plants ranged between 2 to 7 . The highest number of branches was noticed in isolate AUDP48 treated plants (7) followed by AUDT 673 and AUDP 237 of 6 branches. In control it was 5 and in pathogen control it was only 2 . Such beneficial effects due to bacterial inoculation have been reported earlier as well. Recently, Faria et al., (2013) reported enhanced biomass in both shoots and roots of Cattleya seedling due to the application of endophytic Paenibacillus lemtimorbus and $P$. macerans isolates. Inoculation of these isolates enhanced root dry weight up to $305 \%$, root length by to 119 $\%$ and shoot dry weight by to $257 \%$ in plant. In the present study, inoculation of Pseudomonas isolate AUDP48 improved the plant growth parameters as compared to all other isolates.

The results obtained were in agreement with previous work. The work conducted by Rakh et al., (2011) revealed that, improvement in \% germination, shoot length, root length, Number of leaves and chlorophyll content of the treatment by using Pseudomonas $c f$. monteilii 9 as biocontrol agents against Sclerotium rolfsii, causing stem rot disease in groundnut, compared. Similar work by Pastor et al., (2010) showed that Pseudomonas sp. PCI2 against $S$. rolfsii in tomato was used to increase root dry weight $(157 \pm 7.9 \mathrm{mg})$ compared to control plants $(110 \pm 8.2 \mathrm{mg})$. Shoot biomass was slightly greater in inoculated plants $(225 \pm 8.1 \mathrm{mg})$ than in control plants (204 $\pm 7.8 \mathrm{mg})$. Recently, Ganesan and Sekar (2012), showed vigorous growth and healthy looking compared with control plants. The length of the root and shoot, and fresh and dry weight of the shoot and root also increases at different level over control plant Groundnut seeds when treated with Streptomyces sp. strains showed significant increases in root length, shoot length and seedling vigour was noticed by Adhilakshmi et al., (2014). Present work showed that Pseudomonas and actinobacteria could be effectively used to prevent $S$. rolfsii infection and also improves plant growth in Groundnut crop (Arachis hypogaea L.).

\section{References}

Abeygunawardena, D.V.W. and Wood, R.K.S., 1957. Factors affecting the germination of sclerotia and mycelial growth of Sclerotium rolfsii Sacc. Transactions of the British Mycological Society, 40(2):221-231.

Adhilakshmi, M., Latha, P., Paranidharan, V., Balachandar, D., Ganesamurthy, K. and Velazhahan, R., 2014. Biological control of stem rot of groundnut (Arachis hypogaea L.) caused by Sclerotium rolfsii Sacc. with actinomycetes. Archives of Phytopathology and Plant Protection, 47(3):298-311.

Adiver S S (2003),“ Influence of Organic Amendments and Biological Components on Stem Rot of Groundnut", National Seminar on Stress 
Management in Oilseeds For Attaining Self Reliance in Vegetable Oil Indian Society of Oilseeds Research, Directorate of Oilseeds Research, Hyderabad Form January 28 - 30:1517.

Alexander M (1977). Introduction to soil Microbiology, 2nd edn. New york. John wiley and sons. ISBN0-85226-013X.

Anahosur, K.H., 2001. Integrated management of potato Sclerotium wilt caused by Sclerotium rolfsii. Indian Phytopath, 54(2):58-166.

Asghari, M.R. and Mayee, C.D. 1990. Comparative efficiency of management practices on stem and pod rot of groundnut. Indian Phytopath, 44: 328332.

Bagnasco, P., De La Fuente, L., Gualtieri, G., Noya, F. and Arias, A., 1998. Fluorescent Pseudomonas spp. as biocontrol agents against forage legume root pathogenic fungi. Soil Biology and Biochemistry, 30(10):1317-1322.

Bahadur, A., Singh, U. P., Sarma, B. K., Singh, D, P., Singh, K. P. and Singh, A., 2007. Foliar application of plant growth-promoting rhizobacteria increases antifungal compounds in Pea (Pisum sativum) against Erysiphe pisi. Mycobiology, 35(3): 129-134

Biswas, K.K. and Sen, C., 2000. Management of stem rot of groundnut caused by Sclerotium rolfsii through Trichoderma harzianum. Indian Phytopath, 53(3):290-295.

Chanutsa, N., Phonkerd, N. and Bunyatratchata, W., 2014. Potential of Pseudomonas aeruginosa to control Sclerotium rolfsii causing stem rot and collar rot disease of tomato. Journal of Advanced Agricultural Technologies, $1(2)$.

Curl, E.A. and Truelove, B., 1986. Root exudates. In The rhizosphere. Springer publishers, Berlin Heidelberg: 55-92.
Dey, R., Pal, K. K., Bhatt, D. M. and Chauhan, S. M., 2004. Growth promotion and yield enhancement of peanut (Arachis hypogaea L.) by application of plant growth promoting rhizobacteria. Microbiol. Res., 159: 371-394.

Dobbelaere, S., Vanderleyden, J. and Okon, Y., 2003.Plant growth-promoting effects of diazotrophs in the rhizosphere. Critical reviews in plant sciences, 22(2):107-149.

Doley, K. and Jite, P.K., 2013.Management of stem-rot of groundnut (Arachis hypogaea L.) cultivar in field. Notul. Scie. Biol, 5(3), p.316.

FAOSTAT.2011. http://faostat.fao.org.

Faria, D.C., Dias, A.C.F., Melo, I.S. and De Carvalho Costa, F.E., 2013. Endophytic bacteria isolated from orchid and their potential to promote plant growth. World Journal of Microbiol and Biotech, 29(2): 217-221.

Ganesan, P. and Gnanamanickam, S.S., 1987. Biological control of Sclerotium rolfsii Sacc. In peanut by inoculation with Pseudomonas fluorescens. Soil Biol Biochem., 19: 35-38.

Ganesan, S. and Sekar, R., 2012. Fluorescent Pseudomonas as plant growth promoting Rhizobacteria and biocontrol agents in groundnut crop (Arachis hypogaea L.). Int. J. Appli. Bio Res., 12:1-6.

Gopalakrishnan, S., Vadlamudi, S., Bandikinda, P., Sathya, A., Vijayabharathi, R., Rupela, O., Kudapa, H., Katta, K. and Varshney, R.K., 2014. Evaluation of Streptomyces strains isolated from herbal vermicompost for their plant growth-promotion traits in rice. Microbiol. Res., 169(1):40-48.

Ingale, R.V. and Mayee, C.D., 1986. Efficacy and economics of some management practices of fungal diseases of groundnut. J. Oilseeds Res, 3:201-204. 
Kishore, G. K., Pande, S. and Podile, A. R., 2005. Biological control of collar rot disease with broadspectrum antifungal bacteria associated with groundnut. Can. J. Microbio., 51: 123-32.

Kloepper,J.W, Rodriguez-Ubana, R., Zehnder, G.W., Murphy, J.F, Sikora. E., Fernandez, C., 1999. Plant root bacterial interactions in biological control of soil borne diseases and potential extension to systemic and foliar diseases. Austr. Plant Pathol. 28: 21-26.

Kumar, A., Maurya, B.R. and Raghuwanshi, R., 2014. Isolation and characterization of PGPR and their effect on growth, yield and nutrient content in wheat (Triticum aestivum L.). Biocat. Agricul. Biotech, 3(4):121-128.

Mahato, A., Mondal, B., Dhakre, D.S, Khatua, D.C., 2014. In vitro sensitivity of Sclerotium rolfsii towards some fungicides and botanicals. Scholars Acad. J. Biosci., 2(7):467-471.

Mehan, V.K., Mayee, C.D. and McDonald, D., 1994. Management of Sclerotium rolfsii- caused stem and pod rots of groundnut - a critical review.

Muthamilan, M. and Jayarajan, R., 1996. Integrated management of Sclerotium root rot of Groundnut involving, Trichoderma harzianum, Rhizobium and Carbendazim. Indian. J.Mycol. Pl. Pathol, 26: 204-209.

Pastor, N.A, Reynoso, M.M, Tonelli, M.L, Masciarelli, O., Rosaso, S.B, Tonelli, M.L, Masciarelli, D., Rosas, S.B., Rovera, M. Potential bio control Pseudomonas sp. Pc12 against damping-off of tomato caused by Sclerotium rolfsii. 2010. J.Plant Pathol., 92: 737-745.

Punja, Z. K., 1985, the biology, ecology, and control of Sclerotium rolfsii, Annual Rev. Phytopathol., 23: 97-127.

Punja, Z., Sun, L.J., 2001, Genetic diversity among mycelial compatibility groups of
Sclerotium rolfsii (teleomorph Athelia rolfsii) and S. delphinii.Mycol. Res., 105: 537-546.

Raaijmakers, J. M., Vlami, M., and De Souza, J. T., 2002. Antibiotic production by bacterial biocontrol agents. Antonie van Leeuwenhoek. 81: 537-547.

Rakh, R.R., Raut, L.S., Dalvi, S.M. and Manwar, A.V., 2011. Biological control of Sclerotium rolfsii, causing stem rot of groundnut by Pseudomonas cf. monteilii 9. Recent Res. Sci. d Technol. 3(3).

Ramamoorthy, V., Raguchander, T. and Samiyappan, R., 2002. Induction of defense-related proteins in tomato roots treated with Pseudomonas fluorescens Pf1 and Fusarium oxysporum f. sp. lycopersici. Plant and soil, 239(1):5568.

Ramanathan, A., Samiyappan, R. and Vidhyasekaran, P., 2000. Induction of defense mechanisms in greengram leaves and suspension cultured cells by Macrophomina phaseolina and its elicitors. J. Plant Dis. Protect., 107: 245-257.

Rangeshwaran, R. and Prasad, R.D., 2000. Biological control of Sclerotium rot of sunflower. Indian Phytopathology, 53(4), pp.444-449.

Ristaino, J.B., Perry. K.B. and Lumsden, R.D.1991. Effect of Solarization and Gliocladium virens on Sclerotia of Sclerotium rolfsii Soil, Microbiota and the incidance of Southern Blight of Tomato. Phypathol, 81(10): 1117-1124.

Riungu, G. M., Muthorni, J. W., Narla, R. D., Wagacha, J. M. and Gathumbi, J. K.,2008. Management of Fusarium head blight of wheat and deoxynivalenol accumulation using antagonistic microorganisms. Plant Pathol. J., 7(1): 13-19.

Shivakumar, B., 2007. Biocontrol potential and plant growth promotional activity 
of fluorescent pseudomonads of Western Ghats (Doctoral dissertation, UAS, Dharwad).

Soares, A.C.F., Sousa, C. S., Garrido, M.S., Perez, J.O. and Almeida, N.S., 2006. Soil Streptomycetes With In Vitro Activity against the Yam Pathogens Curvularia Eragrostides and Colletotrichum Gloeosporioides. Brazilian J. Microbiol., 37:456-461.

Taechowisan, T., Lu, C., Shen, Y. and Lumyong, S., 2005.Secondary metabolites from endophytic Streptomyces aureofaciens CMUAc130 and their antifungal activity. Microbiol, 151:1691-1695.

Tonelli, M.L., Furlan, A., Taurian, T., Castro, S. and Fabra, A., 2011. Peanut priming induced by biocontrol agents. Physiol Mol Plant Path., 75:100-105.

Tonelli, M.L., Taurian, T., Ibanez, F., Angelini, J. and Fabra, A., 2010. Selection and in vitro characterization of biocontrol agents with potential to protect peanut plants against fungal pathogens. J Plant Pathol, 92:73-82.

Van Loon, L.C., Bakker, P.A.H.M. and Pieterse, C.M.J., 1998. Systemic resistance induced by rhizosphere bacteria. Annual review of phytopathology, 36(1):453-483.

Vessey, J.K., 2003. Plant growth promoting rhizobacteria as biofertilizers. Plant and soil, 255(2):571-586.

Wang, K., Yan, P.S., Ding, Q.L., Wu, Q.X., Wang, Z.B. and Peng, J., 2013. Diversity of culturable rootassociated/endophytic bacteria and their chitinolytic and aflatoxin inhibition activity of peanut plant in China. World J. Microbiol.Biotech., 29(1):1-10.

Zehnder, G.W., Murphy, J.F., Sikora, E.J. and Kloepper, J.W., 2001. Application of rhizobacteria for induced resistance. Eur. J. Pla. Pathol, 107(1):39-50.

\section{How to cite this article:}

Roopa, K.P. and Krishnaraj, P.U. 2017. Effect of Actinobacteria and Pseudomonas spp. against Sclerotium rolfsii in Groundnut. Int.J.Curr.Microbiol.App.Sci. 6(10): 229-245. doi: https://doi.org/10.20546/ijcmas.2017.610.029 